DISCUSSION PAPER

\title{
LANGUAGE SKILLS NEEDS IN BUSINESS ENVIRONMENT
}

\author{
Andrea HOLÚBEKOVÁ *, Mária FÖRDÖSOVÁ
}

Address:

Slovak University of Agriculture in Nitra, Faculty of Economics and Management, Department of Languages, Tr. A. Hlinku 2, 94976 Nitra, Slovakia.

* Corresponding author e-mail: andrea.holubekova@uniag.sk

\begin{abstract}
In the article, results and findings of a survey aimed at identifying language skills needs of Slovak small, medium-sized and large enterprises operating mainly in agriculture and food processing industry are presented. An online questionnaire was constructed to collect data. 14 out of 50 selected companies responded. Our findings revealed the fact that the Slovak enterprises use mainly English and German when communicating with their headquarters, suppliers and customers. The respondents also require their employees to have the following special language skills: communicating on the telephone, conducting business negotiations and writing business letters in a foreign language. As for language management strategies, the enterprises organize language training courses for their employees within their premises or the employees have to attend language courses outside the premises. The results of the survey conducted in Slovakia and the EU surveys were compared. Based on the results, we suggest stronger cooperation between the SMEs and universities in Slovakia in production of graduates better equipped with the language skills required by the business environment.
\end{abstract}

Keywords: enterprise, language skills needs, questionnaire JEL: J24, M53

\section{INTRODUCTION}

One of the policies of the European Union is the language policy which "is based on respect for linguistic diversity in all Member States and on the creation of an intercultural dialogue throughout the EU. In order to put mutual respect into practice, the EU promotes the teaching and learning of foreign languages and the mobility of every citizen through dedicated programmes for education and vocational training. Foreign language competence is regarded as one of the basic skills that all EU citizens need to acquire in order to improve their educational and employment opportunities. The EU therefore supports the idea that every citizen should master two foreign languages in addition to his or her mother tongue" (European Parliament, 2017).

It could be claimed that nowadays, the necessity of a good command of foreign languages goes hand in hand with successful expanding of a company's business into foreign markets. European institutions have initiated a few surveys, projects and studies investigating the linkage between language skills of small, medium sized and large enterprises and their business performance. The ELAN study (European Commission, 2006) was undertaken by CILT (the UK National Centre for Languages). The main objective of this study was to analyse the impact of language skills of small and medium-sized enterprises (SMEs) on their business performance as well as to compare the language skills of SMEs with those used by multinational companies. The subjects of the ELAN study were 2000 SMEs from 29 European states and 30 large multinational companies. The findings revealed the fact that "a significant amount of business is being lost as a result of lack of language skills. [...] 11\% of respondents (195 SMEs) lost a contract as a result of lack of language skills. Many were unable or unwilling to indicate the size of the contract lost, but 37 businesses had lost actual contracts which together were valued at between $€ 8$ million and $€ 13.5$ million. A further 54 businesses had lost potential contracts worth in total between $€ 16.5$ million and $€ 25.3$ million. At least 10 businesses had lost contracts worth over $€ 1$ million" (European Commission, 2006).

According to the European Commission (2006), the main languages used by SMEs for communicating on the international market are English, German, French, Russian, Spanish and others. Large multinational companies also claimed that they prefer English as a lingua franca when communicating internationally but on the other hand, they value the knowledge of other global languages such as Spanish, Chinese, Arabic, Portuguese and others. As for special language skills, among the companies there is a demand mainly for: English for negotiations, English for meetings, English for exhibition and English for correspondence, German for negotiations and correspondence, French for negotiations, etc. When doing business internationally, companies usually use different language management strategies. A language management strategy is "a company's package of measures and techniques used to prevent linguistic and cultural barriers from occurring in new and expanding foreign markets" (European Union, 2011). In 15 of the 29 countries at least $50 \%$ of enterprises maintained that 
they have a language strategy in order to support effective communication with their clients and suppliers abroad, e.g. language training for employees, recruiting a native speaker with language skills etc. The companies also want to invest into language strategies in the future because they are planning to expand into new foreign markets and using appropriate language strategies can help them overcome potential linguistic difficulties (European Commission, 2006).

Later, in 2001, the European Commission (2011) published the outcomes of the PIMLICO survey which was conducted in order to promote the greater use of foreign languages by SMEs. The subjects of the survey were 40 small and medium-sized international companies from 27 Member States of the European Union. One of the aims of a team of international researchers, who interviewed the selected companies, was to collect information about companies' language and communication strategies used to overcome problems in international trade. For example, the main language management strategies used by the selected companies participating in the PIMLICO study are: high-level competence in English (but also in other languages in order to suit the specifics of marketplace), use of local agents for linguistic and cultural purposes, use of native speakers, linguistic and cultural training (e.g. language courses or buying online language learning programmes), use of professional translators, multilingual website development or use of universities (e.g. hiring language graduates and placing foreign students inside the companies or using language learning facilities of universities). The findings of the study point out the fact that a successful language strategy used by 40 European SMEs increased the sales turnover of $3 / 4$ of the companies by at least $16 \%$ through their appropriate language management. Therefore, one recommendation of the PIMLICO research team for the companies which want to enter a foreign market is to use appropriate language strategies and also adopt them to new cultural and linguistic needs. Because good language management strategies can help the companies start exporting, and then the European Union economy will benefit as well as the companies.

Furthermore, from 2011 to 2013, the European Commission funded the project called CELAN. The main aim of the project was to "create a network that provides language services to business stakeholders" (CELAN, 2013a). The target groups of the project were enterprises (in particular SMEs), workers, business representative organisations, social partners as well as higher education institutions (CELAN, 2013b). Within the project, the Language Needs Questionnaire was published in order to gather information about language needs of companies. The questionnaire was completed by over 500 professional users. Then, the Language Needs Analysis Application was created on the basis of the results from the survey. The Application is "an interactive system allowing business users to profile their language needs, compare these with current practice, and gain information and access to a range of various language resources available in the language community and market" (CELAN, 2013c). As mentioned above, some successful export companies put emphasis on their cooperation with universities. Therefore, the CELAN project's participants were also universities in order to find out which language courses and other services they offer. According to the results, the universities surveyed by the project "offer a variety of language courses at both the Bachelor's and Master's levels for credits. [...] participant universities tend to offer courses taught in other languages of instruction for students of specific disciplines, mostly in areas such as business communication, [...] and economics [...]. In many cases, the learning outcomes are clearly defined, with the target of preparing students for the labour market" (CELAN, 2013d). Thus, fostering language skills meeting the demands of labour market should be one of the priorities of universities. In addition, CELAN results can also contribute "to the realisation of the European Commission's policy aim to promote successful entrepreneurship and to improve the business environment for SMEs" (CELAN, 2013b).

Also Slovak non-philological universities offer a wide variety of language courses. Some of the courses are aimed at acquisition of language skills for general communication use and the others at mastering the Language for Specific Purposes (Zelinková, 2016 and Bátovská, 2016). As for the Language for Specific Purposes courses, the language instruction is focused on a specific context within which the language is used (e.g. English for Economics, German for Economics, Russian for Medical Studies, French for Technicians, etc.).

The phenomenon of the courses dealing with the Language for Specific Purposes (LSP) was developed in the English context after the Second World War. That is why a lot of works on LSP are based on the studies connected with the English for Specific Purposes (ESP). Hutchinson and Waters (1990) identified three main reasons which led to the emergence of the English for Specific Purposes courses:

- Demand of a new generation of learners who knew why they were learning a foreign language (e.g. businessmen who wanted to sell their products);

- A revolution in linguistics connected with the development of English courses for specific groups of learners (a shift from learning the language rules to identifying the needs of learners);

- Focus on the learners by taking into account their attitudes to learning and identifying their different needs and interests.

Within ESP/LSP courses all the decisions about the content and methods used are based on the reasons why the learners need to learn the language and in which situations they want to use it. Because ESP/LSP is an approach to language learning and teaching whose aim is to meet the demands of learners, the role of ESP/LSP teachers is to design courses tailored for those specific groups of learners. Thus, the main emphasis of course designers should be put on identifying learners' target needs - what they need to do in the target situation, and learning needs - what they need to do in order to learn (Hutchinson and Waters, 1990). Therefore the ESP/LSP 
course designers have to undertake the so-called Needs Analysis. The Needs Analysis usually takes the form of a questionnaire aimed at identifying the specific needs of the target group of learners. According to the results of a questionnaire survey, the ESP/LSP teachers are able to create an appropriate syllabus for their learners.

But at present, when many companies trade internationally, it is not important only to identify the language skills needs of learners but also the language skills needs of companies because, as stated above, the lack of appropriate language skills can lead to losing important international contracts. Therefore, in the article, the centre of the interest will be put on identifying the language skills needs of Slovak companies. Consequently, the findings of the survey will be compared with the findings of surveys initiated by the European Union and presented above.

\section{DATA AND METHODS}

The main tool used for collecting information about language skills needs of Slovak enterprises was an anonymous questionnaire (Appendix 1) which was completed on-line by the respondents from November to December 2016. Eleven close-ended questions where the respondents had to pick from the pre-determined set of answers were used. First two questions were aimed at determining the size of enterprises and which sector of economy they belong to. The following questions were focused on identifying:

- if the knowledge of foreign languages is important for the companies;

- which foreign languages are important for the successful performance of the companies internationally;

- which employees in the companies should have a good command of foreign languages;

- how the future employees have to prove their knowledge of foreign languages;

- which situations the foreign languages are used in the companies;

- if a good command of a Foreign Language for Specific purposes is important for the companies;

- which basic foreign language skills are required of the employees of the companies;

- which foreign language microskills are required of the employees of the companies;

- $\quad$ which language strategies are used by the companies. Within questions $4,5,6,7,9,10,11$, the respondents were allowed to mark more than one option.

\section{RESULTS AND DISCUSSIONS}

The questionnaire was sent on-line to 50 enterprises (mainly from agriculture and food processing industry), but only 14 of them (28\%) answered the questions. The respondents of the questionnaire were small (1), mediumsized (6) and large (7) enterprises (Figure 1).

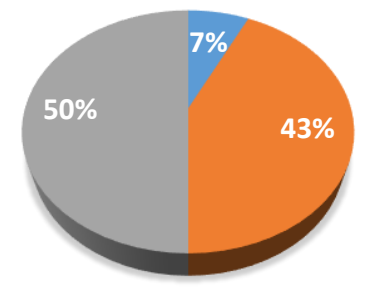

\section{small enterprises \\ medium-sized enterprises \\ - large enterprises}

Figure 1 Structure of respondents (enterprises) according to number of employees

Source: Own processing

Across the sample of 14 respondents, $7.1 \%$ of the companies belong to the tertiary sector, $14.3 \%$ to the quaternary sector, $21.4 \%$ to the primary sector and $57.1 \%$ to the secondary sector of economy. On the one hand, according to $92.9 \%$ of the enterprises, the knowledge of foreign languages is important for them because of better competitiveness on the international market. On the other hand, only for $7.1 \%$ of the companies, the knowledge of foreign languages is not so important.

As for foreign languages, the following languages are crucial for the successful performance of the companies on the international market (written in the order of importance):
a. English - 13;
b. German - 11;
c. Russian -4 ;
d. French -1 ;
e. Spanish - 1;
f. Italian -1 ;
g. other languages -1 .

The responses to this question show that English and German are the most widely used languages within the enterprises. This is due to the fact that English is a common lingua franca in the world of business across the globe and the usage of German corresponds to the geographical position of Slovakia in Europe and also to its close economic relations to Germany and Austria.

Within Question 5, the respondents had to mark which employees should have a good command of the above mentioned foreign languages. The results are as follows:

- $\quad$ top management of the company $(85.7 \%)$;

- middle management of the company (71.4\%);

- $\quad$ other employees (14.3\%);

- all employees of the company (14.3\%).

To sum it up, mainly, the top management of the companies together with the middle management of the companies are required to have a good command of foreign languages.

Question 6 was closely connected with the previous one and the aim was to find out which of the employees marked in Question 5 had to, during the recruitment process,: 
- conduct the interview in a foreign language $(85.7 \%)$;

- $\quad$ write a CV in a foreign language (50\%);

- write a covering letter in a foreign language $(14.3 \%)$.

The companies place emphasis on foreign language skills of their employees at the very beginning of the recruitment process because potential employees had to write their $\mathrm{CVs}$ in a foreign language and subsequently the shortlisted candidates were interviewed in a foreign language as well. Only in two companies, the candidates were also asked to write covering letters in a foreign language.

The employees of the companies have to use the foreign languages mainly in the following situations (Figure 2):

a. in communication with customers $(71.4 \%)$;

b. in communication with the headquarters of the company abroad $(64.3 \%)$;

c. in communication with suppliers $(64.3 \%)$;

d. others $(7.1 \%)$.

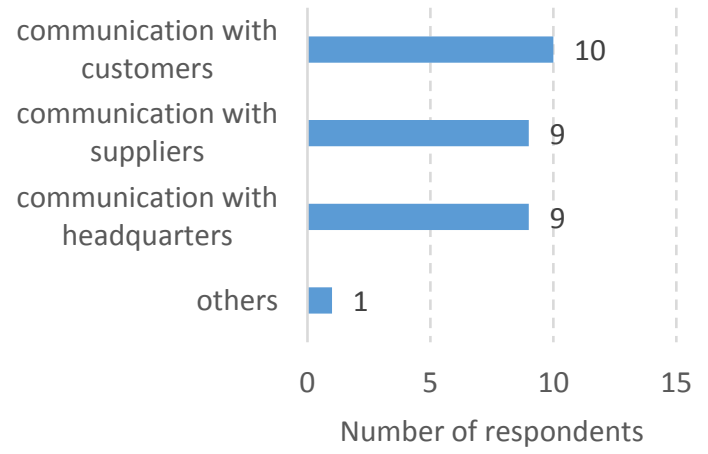

Figure 2 Situations in which foreign languages are used Source: Own processing

It is worth reporting that the knowledge of foreign languages is important when dealing not only with the headquarters of the companies abroad but also when communicating with both, customers and suppliers.

Because we think that the employees of the companies operating internationally have to master a foreign Language for Specific Purposes as well, Question 8 was focused on confirming this assumption. The results were not surprising - all the respondents (100\%) think that the command of the foreign Language for Specific Purposes is important for their employees (or future employees) in order to be able to fulfil their tasks internationally.

Furthermore, the importance of main language skills was questioned. All of those asked think that listening comprehension and speaking are crucial; $71.4 \%$ of them prefer writing and $64.3 \%$ of respondents put emphasis on reading comprehension.

Question 10 was aimed at identifying which microskills connected with the Foreign Language for Specific Purposes are valued in the companies. For the companies, the most important ones are: a. telephone conversations $(100 \%)$;

b. business negotiations $(92.9 \%)$;

c. business correspondence $(64.3 \%)$;

d. presentations $(57.1 \%)$;

e. small talk $(57.1 \%)$;

f. writing minutes, note taking $(35.7 \%)$;

g. other skills $(28.6 \%)$.

For all the respondents, the ability to communicate effectively on the telephone is the main foreign language microskill. A significant percentage of companies, $92.9 \%$ of the total sample, value conducting business negotiations in a foreign language. For $64.3 \%$ of the companies, business correspondence in a foreign language is important; then presentations, small talk, and writing minutes and note taking follow.

At the end, language strategies of the companies were investigated. According to 11 of them, the best language strategy is organizing language courses for their employees within the premises of the company (paid by the company). Only four of the respondents think that individual language courses outside the company (language schools, paid by employees themselves) should play a key role in forcing their employees to learn a foreign language. Other strategies are preferred by one company. None of the respondents marked the option internship in a foreign country (Figure 3 ). These findings may reflect the fact that the managers of the companies put emphasis on the importance of foreign language skills of their employees and therefore, they arrange free language training courses for them within the premises.

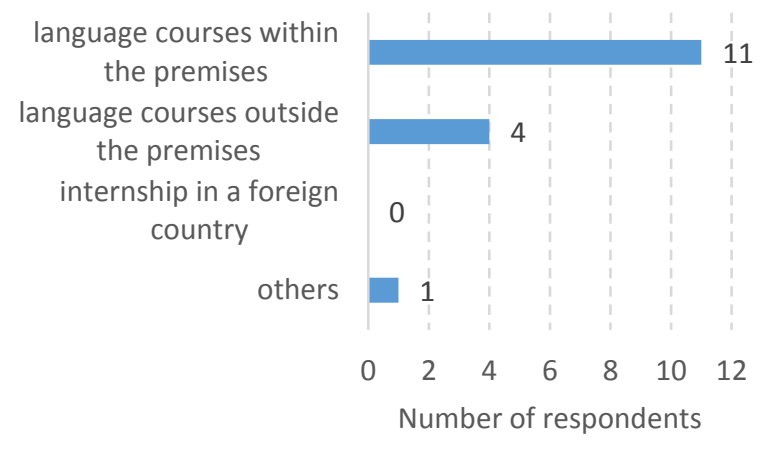

Figure 3 Language strategies

Source: Own processing

\section{CONCLUSION}

From the results gathered in the survey it is possible to conclude that also Slovak enterprises place great emphasis on language skills of their employees in order to be able to achieve better access to foreign markets and not to lose important business contracts. The Slovak companies engaged in our survey use mainly English, a lingua franca, and German when communicating internationally. It is in accordance with the results of the surveys initiated by the European Commission. For example, according to the ELAN study undertaken by the European Commission (2006), the main languages used by European SMEs and 
large multinational companies are English and German, but on the other hand, the companies also value the knowledge of other global languages such as Spanish, Chinese, Arabic or Portuguese. Also the findings of the European Commission (2011) survey point out the fact that the companies surveyed put emphasis on high-level competence in English. The top management and middle management of Slovak enterprises are required to have a good command of foreign languages to communicate effectively with the companies' headquarters as well as with their international customers and suppliers. Our findings also show that following skills in a foreign language are valued by the Slovak enterprises: speaking and listening (telephone conversations, business negotiations and presentations, small talk), writing (business correspondence, writing minutes, note taking) and reading. As for the ELAN study - European Commission (2006), the enterprises participating in the survey value mainly speaking (negotiations and meetings) and writing (correspondence) in different foreign languages. The results of the European Commission, (2006) and European Commission (2011) studies also revealed the fact that the enterprises which want to operate internationally should use effective language management strategies to overcome possible difficulties. The language strategies employed by the companies are: language training for staff, recruiting a native speaker, multilingual websites, cooperation with universities, etc. The Slovak enterprises involved in our survey place emphasis mainly on language training of their employees. It has to be stressed that the Slovak companies should use a wider range of language management strategies in order to overcome possible problems related to insufficient knowledge of foreign languages.

To conclude, the foreign language skills of employees of Slovak small, medium-sized and large enterprises are crucial for the companies' future development and position on the international market. But the Slovak companies should use more language management strategies. We suggest mainly cooperation of Slovak companies with universities. The main objective of universities, especially non-philological ones, has to be to help their students acquire adequate language skills in order to fulfil the language requirements of enterprises, the future employers of their graduates. As a result, departments of languages at non-philological universities should focus on teaching those foreign language skills which are in accordance with the demands of SMEs. And thus, one of the language management strategies of enterprise - cooperation with universities- will be put into practice.

\section{REFERENCES}

BÁTOVSKÁ, M. (2016): Výučba odborného ruského jazyka na vybraných fakultách ekonomického zamerania. Bc. The Slovak University of Agriculture in Nitra.

CELAN. (2013a): Language Strategies for Competitiveness and Employability: Origins. [online] Available at: http://www.celan-platform.eu/index.html [Accessed 21 June 2017]

CELAN. (2013b): Network for Promotion of Language
Strategies for Competitiveness and Employability. [online] Available at: https://www.eurashe.eu/library/modernisingthe/CELAN_report final_public.pdf [Accessed 21 June 2017

CELAN. (2013c): Language Needs Analysis Application. [online] Available at: http://www.celanplatform.eu/language_needs_analysis.html [Accessed 21 June 2017]

CELAN. (2013d): Report of the Results of a Survey Conducted Among Networks of Higher Education Institutions. [online] Available at: http://www.celanplatform.eu/assets/files/CELAN D2-3 Report-2.pdf

[Accessed 21 June 2017]

EUROPEAN COMMISSION. (2006): Elan: Effects on the European Economy of Shortages of Foreign Language Skills in Enterprise. [online] Available at: http://ec.europa.eu/dgs/education_culture/repository/lang uages/policy/strategic-framework/documents/elan_en.pdf [Accessed 21 June 2017]

EUROPEAN COMMISSION. (2011): Report on Language Management Strategies and Best Practice in European SMEs: The PIMLICO Project. [online] Available

http://ec.europa.eu/dgs/education_culture/repository/lang uages/policy/strategic-framework/documents/pimlicofull-report en.pdf [Accessed 12 September 2017] EUROPEAN PARLIAMENT. (2017): Language Policy. [online] Available at: http://www.europarl.europa.eu/atyourservice/en/displayF tu.html?ftuId=FTU 5.13.6.html [Accessed 21 June 2017] EUROPEAN UNION. (2011): The Language Guide for European Business: Successful Communication in your international trade. [online] Available at: https://publications.europa.eu/en/publication-detail//publication/8a7af623-4ec8-4cf6-8632-99fad992187c

[Accessed 21 June 2017]

HUTCHINSON, T., WATERS, A. (1990): English for Specific Purposes. Cambridge :Cambridge University Press, p. 183

ZELINKOVÁ, L. (2016): Výučba odborného anglického jazyka na vybraných fakultách ekonomického zamerania. Bc. The Slovak University of Agriculture in Nitra.

\section{Appendix 1 Questionnaire: Needs analysis}

1. Sector of economy where your company belongs to:

a. primary (agriculture, extraction of raw materials, forestry, power industry)

b. secondary (manufacturing industry, building industry)

c. tertiary (commercial services transportation, trade, telecommunications)

d. quaternary (science, technologies, education, healthcare)

2. Type of your enterprise:

a. a small enterprise (up to 49 employees)

b. a medium-sized enterprise (up to 249 employees)

c. a large enterprise (250 and more employees) 
3. Is knowledge of foreign languages important for your company in the context of competitiveness on the market?
a. yes

b. no

4. Which of the following languages are important for the successful performance of your company internationally? (you can mark more than one option)
a. English
b. French
c. German
d. Russian
e. Spanish
f. Italian
g. Chinese
h. others

5. Which employees in your company should have a good command of foreign languages? (you can mark more than one option)

a. top management of the company

b. middle management of your company

c. other employees

d. all employees of the company

6. When you hire the employees marked in Question 5, do you require them to (you can mark more than one option):

a. conduct the interview in a foreign language

b. write a $\mathrm{CV}$ in a foreign language

c. write a covering letter in a foreign language?

7. Which situations are foreign languages used in your company? (you can mark more than one option)

a. in communication with customers

b. in communication with suppliers

c. in communication with the headquarters of the company abroad
8. Do you think that your employees (or future employees) should also master a Foreign Language for Specific Purposes?
a. yes
b. no

9. Which of the following skills in a foreign language are required of your employees? (you can mark more than one option)
a. reading comprehension
b. writing
c. listening comprehension and speaking

10. Which of the following foreign language microskills are required of your employees? (you can mark more than one option)
a. telephone conversation
b. business negotiations
c. small talk
d. presentations (e.g. an official company presentation)
e. business correspondence
f. writing minutes, note taking
g. others

11. What is the language strategy of your company? (you can mark more than one option)
a. organizing language courses for employees within the premises of the company (paid by the company)
b. individual language courses outside the company (language schools, paid by employees themselves)
c. internship of the employees in foreign countries
d. others 